\title{
DYLEMATY MORALNE I KONFLIKTY POWINNOŚCI W POLSKIM SYSTEMIE OPIEKI ZDROWOTNEJ A PROBLEM RYZYKA ZDROWOTNEGO
}

\section{Konflikty i dylematy moralne w opiece zdrowotnej}

Pojęcia „,konflikt” i „dylemat” stosowane są w życiu codziennym na określenie różnych sytuacji, choć zakresowo mają wiele wspólnego. Kiedy używamy pojęcia dylemat mamy na myśli głównie sytuację trudnego wyboru między dwiema lub wieloma możliwościami. Dylemat moralny zazwyczaj związany jest $\mathrm{z}$ nierozwiązywalnym konfliktem dwóch równoważnych powinności [Aszyk: 1998]. Z kolei gdy mówimy o domniemanym lub rzeczywistym konflikcie wskazujemy na sytuację niezgody, kolizji różnych czynników takich jak interesy, postawy, wartości, działania. Dylematy moralne dotyczą sytuacji wyborów w świecie rzeczywistym, w praktykach działania lekarza, pielęgniarki czy naukowca - jeśli ograniczyć się do przykładów z dziedziny medycyny. Kiedy mówimy zaś o dylematach etycznych mamy zazwyczaj na uwadze intelektualny opis i dyskurs teoretyczny pomiędzy przedstawicielami różnych orientacji etycznych i światopoglądowych. Warto zwrócić uwagę na to, że wybory moralne mają konkretne konsekwencje dla praktyki zawodowej lekarza a ich skutki odczuwają pacjenci bezpośrednio. Dynamiczny rozwój nowoczesnej biomedycyny i biotechnologii spowodował, że coraz częściej lekarskie dylematy moralne wykraczają poza medycynę kliniczną i dotyczą uniwersalnych konfliktów wartości. Wartość życia i zdrowia ludzkiego może być różnie definiowana i ustawiana w hierarchii innych wartości, co implikuje wiele sporów etycznych [Ślęczek-Czakon: 2004]. Różnice w argumentacji uzasadniających wartość życia ludzkiego pomiędzy absolutystą i relatywistą moralnym mają swój wymiar praktyczny w procedurach medycznych. Dylematy moralne pojawiające się w praktykach zawodowych lekarzy i badaniach klinicznych są przedmiotem badań i opisu w ramach etyki lekarskiej i bioetyki. Ponieważ z samej istoty dylematów 
wynika, że dokonywane wybory mogą nieść określone ryzyko zdrowotne, konieczne jest ustalenie zasad etycznych, którymi biorące udział w podejmowaniu decyzji osoby powinny się kierować. Wszak medycyna ma leczyć, ratować życie, minimalizować cierpienie. Analiza kazusów medycznych dostarcza pretekstu do namysłu etycznego i ustanawiania zasad postępowania w sytuacjach konfliktu wartości. Podejmowanie decyzji w sytuacjach medycznie trudnych uwikłane jest nie tylko w procedury i standardy techniczne postępowania lekarskiego ale uwarunkowane jest również konfliktami wartości, będącymi wyrazem uznania dla odmiennych systemów filozoficznych [Purtilo 2005]. Przykładem może być dyskurs pomiędzy zasadą świętości życia a zasadą jakości życia, stanowiącymi fundament różnych orientacji filozoficznych. Jako konflikt wartości podaje się takie sytuacje, w których (...) określone wartości wykluczaja się nawzajem, wskutek czego urzeczywistnienie jednej wartości nie może się dokonać inaczej, jak poprzez poświęcenie innej wartości [Ślipko: 2002: 230]. Dyskurs bioetyczny przeniesiony jest na forum publiczne, uczestniczą w nim różne podmioty i instytucje lecz konsekwencje, w postaci regulacji prawnych bądź zasad deontologicznych mają skutki w praktykach lekarskich. Przykładem może być dyskusja publiczna $\mathrm{w}$ związku $\mathrm{z}$ ustaleniem regulacji prawnych dotyczących zapłodnienia in vitro. Punktem niezgody są procedury kliniczne dopuszczające różne techniki zapłodnienia zaś jądro sporu dotyczy ustaleń metafizycznych i aksjologicznych, np. o status ontologiczny zygoty. W profesji lekarskiej najważniejszy stał się wymiar kognitywny, w mniejszym stopniu wymiar empatyczny. Badania potwierdzają, że lekarze szukają w kodeksach deontologicznych i prawnych rozwiązań, które mogliby bez zastrzeżeń i dylematów moralnych stosować $w$ swoich praktykach zawodowych, nie widzą też potrzeby empatii $\mathrm{w}$ relacjach $\mathrm{z}$ pacjentami, co wpisuje się $\mathrm{w}$ zmiany postrzegania zawodu jako profesji eksperckiej, a nie zgodnie z tradycją „,sztuki leczenia”. Wśród cech opisujących profesjonalizm współczesnego lekarza szeroka wiedza i kompetencje zawodowe wskazywane były przez $80 \%$ respondentów, zaś altruizm tylko przez 19\% [Studzińska-Pasieka: 2010]. Posługiwanie się kazusami medycznymi budzącymi dylematy moralne odnoszone jest zazwyczaj do przyjętego przez zainteresowanych systemu aksjologicznego oraz zasad deontologicznych zawodu lekarskiego, co w perspektywie konfliktu pozwala na skorzystanie z tzw. klauzuli sumienia. Kluczowe dla porządkowania i rozwiązywania dylematów są cele medycyny i zasady etyczne opracowane przez różne gremia, w skład których wchodzą zazwyczaj lekarze, etycy, teologowie, a także politycy i ekonomiści. Ważne dla profesjonalizacji międzynarodowej bioetyki był zredagowany przez D. Callahana a przygotowany zespołowo projekt Centrum w Hastings (Hastings Center) dotyczący $\mathrm{m}$. in. celów medycyny. Ustalono priorytety obowiązujące środowisko biomedyczne: 1) zapobieganie chorobom i urazom oraz promocja i utrzymanie zdrowia, 2) usuwanie bólu i cierpienia spowodowanego chorobami, 3) leczenie i troska o ludzi chorych i ,tylko" troska o tych, których nie można 
wyleczyć, 4) unikanie przedwczesnej i dążenie do spokojnej śmierci [Hansen, Callahan: 1999]. Szukanie zasad moralnych, którymi mieliby się kierować przedstawiciele nauk biomedycznych stało się wręcz modne w sytuacji ogólnego kryzysu moralnego i rozpadu wartości uniwersalnych [Mariański: 2001]. Wzorem dla europejskich ustaleń w tym zakresie może być stanowisko etyczne prezentowane przez Beauchampa i Chidressa [1996], które oparte było na czterech powszechnie uznawanych, fundamentalnych zasadach moralnych: poszanowania autonomii, czynienia dobra, nieszkodzenia i sprawiedliwości. Istotne dla stosowania tych zasad jest sformułowanie prima facie, które znaczy, że dana zasada obowiązuje, jeśli nie wchodzi w konflikt $\mathrm{z}$ inną zasadą moralną. $\mathrm{W}$ takich sytuacjach trzeba jedną z nich wybrać i stosować. Proponowane przez autorów zasady moralne w praktyce zawodowej lekarzy wymagają pewnej koordynacji i decyzji, która z nich w konkretnym przypadku staje się priorytetowa. W Europie etyka pryncypiów jest obecna w projekcie BIOMED II, znanym pod nazwą Deklaracji barcelońskiej [1998], której idee rekomendowano Komisji Europejskiej. Za podstawowe zasady uznano: autonomię, godność, integralność, wrażliwość na zranienie (vulnerability). W praktykach zawodowych lekarzy problemem głównym jest znajomość zasad bioetycznych, kodeksu deontologicznego oraz prawa, a następnie przestrzeganie ich w konkretnych sytuacjach medycznych. Szczególnie ryzyko medyczne związane z nowoczesnymi biotechnologiami wymaga ostrożności i cnoty roztropności. Czy ciężar aksjologicznego wyboru jest po stronie badacza-naukowca, lekarza-klinicysty czy może pacjenta? Zawód lekarza wymaga szczególnego społecznego zaufania, a badania opinii społecznej pokazują, że lekarze tracą zaufanie i prestiż społeczny. Należy sądzić, że w postrzeganiu społecznym lekarze zaklasyfikowani zostali jako zawód dobrze sobie radzący w sytuacjach rynkowych, dbający o swoje dochody i spełniający kryteria sukcesu życiowego. Natomiast powinności moralne wobec pacjentów zostały zinstrumentalizowane na tyle, że zasady etyki troski stają się raczej przedmiotem sporów bioetycznych, a w znacznie mniejszym stopniu przenikaja do praktyk zawodowych lekarzy. W komunikacji lekarz-pacjent istnieją zakłócenia, których istota tkwi właśnie w słabej internalizacji zasad etyki troski. W polskim systemie opieki zdrowotnej dominującym modelem relacji lekarzpacjent jest paternalizm, a poszanowanie autonomii pacjenta raczej figurą retoryczną. Przechodzenie do modelu wspólnego naradzania się, w którym lekarz $\mathrm{z}$ troską toczy dialog z pacjentem i wsłuchuje się w jego problemy aby wybrać najodpowiedniejszą metodę leczenia, wymaga długiego procesu socjalizacji i nauczania zawodu lekarza $\mathrm{w}$ duchu kultury dialogu i poszanowania podmiotowości innego [Gordon, Edwards: 2009]. Według niniejszej oceny dylematy i konflikty moralne pojawiają się na wszystkich poziomach funkcjonowania systemu opieki zdrowotnej. Ponieważ w skład systemu zdrowotnego wchodzą m. in. polityka zdrowotna, instytucje, prawo, administracja, personel medyczny, pacjenci, dylematy dotyczą różnych sfer i relacji części funkcjonowania systemu 
zdrowotnego. Można wyodrębnić trzy poziomy funkcjonowania systemu zdrowotnego, którego dotyczą dylematy i konflikty moralne:

- poziom makro-dylematów i konfliktów związany jest z funkcjonowaniem systemu zdrowotnego oraz polityki zdrowotnej: polityka zdrowotna państwa, zarządzanie systemem zdrowotnym, wyodrębnianie się komercyjnych usług zdrowotnych, poprawa relacji pomiędzy publicznym a komercyjnym świadczeniem usług medycznych;

- poziom mezo-dylematów i konfliktów dotyczy instytucji i organizacji średniego szczebla odpowiedzialnych za funkcjonowanie systemu zdrowotnego: polityka samorządów lokalnych, zarządzanie szpitalami i innymi zakładami opieki zdrowotnej;

- poziom mikro-dylematów i konfliktów obejmuje aspekt osobowy i interpersonalny usług zdrowotnych: relacje lekarz-pacjent, relacje wewnątrz personelu medycznego oraz z interesantami.

Wyodrębnienie poziomów dylematów i konfliktów ma charakter analityczny, w sytuacjach empirycznych występuje ich kontaminacja i współzależność. Przyjmowane $w$ trakcie reformowania systemu zdrowotnego rozwiązania organizacyjne i prawne rozmywają podział kompetencji, zadań i odpowiedzialności. Jednym z przykładów konfliktów społecznych w systemie opieki zdrowotnej są strajki pielęgniarek i lekarzy, które niosą ryzyko zdrowotne dla pacjentów. Ze względu na zakres występowania i intensywność strajki mogą dotyczyć poziomu makro bądź mezo (np. wstrzymanie pracy na oddziale szpitala w Krośnie), zaś ich negatywne skutki ponoszone są przez chorych. Lekarze biorący udział w strajkach zapewne odczuwają konflikt psychologiczny, przejawiający się w negatywnych przeżyciach w związku z odmową świadczenia pracy. Świadomość, że dla niektórych pacjentów działanie takie może przyczynić się do pogorszenia stanu zdrowia, a nawet śmierci powinno prowadzić do dyskomfortu psychicznego. Wybór pomiędzy interesem korporacyjnym (udział w strajku) a interesem jednostkowego pacjenta powinien stać się powodem dramatycznych napięć i walk wewnętrznych. Czy faktycznie lekarze odczuwają stany dyskomfortu psychicznego? Jakie racje korporacji zawodowej lekarzy czy pielęgniarek są ważniejsze od potrzeb zdrowotnych jednostkowego pacjenta? Czy w imię interesu grupowego lekarzy można złożyć w ofierze ból i cierpienia pacjenta? Lekarze neutralizują owe dylematy zazwyczaj wprowadzając w postulaty strajkowe punkt dotyczący interesu pacjenta, o który także walczą (np. poprawa warunków pracy, więcej czasu dla pacjenta, lepsze kontakt z chorym). Wyeksponowanie interesu pacjenta usprawiedliwia, częstą w przypadkach strajków lekarzy, dramaturgię ewakuacji pacjentów z objętych strajkiem oddziałów szpitalnych. 


\section{Reforma systemu zdrowotnego i dylematy moralne}

Pojęcie „system ochrony zdrowia" używa się wymiennie z innymi, zakresowo podobnymi pojęciami, jak ,system zdrowotny”, ,system medyczny”, ,,system opieki zdrowotnej”, ,system służby zdrowia”. W skład współczesnego systemu zdrowotnego wchodzą trzy obszary działań:

- profilaktyka rozumiana jako prewencja i zapobieganie chorobom, nastawiona jest na człowieka zdrowego, którego należy edukować i mobilizować do dbania o własne zdrowie, poprawę jakości życia oraz realizację prozdrowotnych stylów życia,

- lecznictwo nastawione na rozpoznawanie i zwalczanie choroby, naprawianie „zepsutej” części organizmu ludzkiego, aktywizację czynników chroniących i redukcję czynników ryzyka celem wzmocnienia potencjału zdrowotnego i powrotu chorego do realizacji społecznych ról,

- rehabilitacja, której zadaniem jest przywracanie zdrowia, sprawności i przydatności społecznej ludziom dotkniętym kalectwem, niepełnosprawnością fizyczną lub psychiczną, udzielanie wsparcia w celu poprawy jakości życia.

System opieki zdrowotnej musi uwzględniać wszystkie obszary działań medycyny, stwarzać warunki instytucjonalne dla opieki realizowanej w trzech pionach: lecznictwie otwartym (przychodnie w zakresie opieki podstawowej i specjalistycznej, gabinety specjalistyczne, zakładowa opieka), lecznictwie zamkniętym (kliniki, szpitale, sanatoria), pomocy doraźnej (ratownictwo medyczne). W literaturze tematu zwraca się uwagę na to, że system jest pewną całością składającą się z m. in. ludzi, procesów, produktów, usług, „które są powiązane wspólnym celem" [Włodarczyk, Paździoch: 2001:14 ]. Konflikty i dylematy pojawiają się we wszystkich obszarach i pionach funkcjonowania systemu ochrony zdrowia, zależą też w dużej mierze od tego jakie cele i zadania ma do zrealizowania opieka zdrowotna. Cele systemu są różnie artykułowane przez poszczególne państwa. Warto odwołać się do podstawowego standardu: Celem każdego systemu medycznego jest organizowanie, produkowanie $i$ udzielanie świadczeń zdrowotnych tym, którzy tych świadczeń potrzebuja, oraz używanie dostęnych zasobów, wiedzy i technologii po to, by zapobiegać i przynosić ulge $w$ chorobie, niesprawności i cierpieniu $w$ zakresie możliwym $w$ istniejacych warunkach [Włodarczyk, Paździoch: 2001: 29]. Eksperci WHO wskazują na trzy podstawowe cele, które powinny realizować systemy zdrowotne: 1) poprawa stanu zdrowia ludności korzystającej z usług medycznych, 2) spełnienie oczekiwań społecznych, 3) zabezpieczenie kosztów opieki związanej z utratą zdrowia [WHO: 2000: 206]. Ważnym składnikiem w większości państw (np. we wszystkich krajach G7) jest indywidualna odpowiedzialność za zdrowie. Obok tej zasady w Niemczech system zdrowotny opiera się na: zasadzie solidaryzmu społecznego, sprawiedliwości i równości w dostępie do pomocy niezależnie od sta- 
nu zdrowia, wolnym wyborze lekarza, wolnej pracy profesjonalistów opieki zdrowotnej [WHO: 1999: 46]. W Polsce, z punktu widzenia obywateli najważniejsze są:

- dostępność do usług medycznych ogólnych, specjalistycznych, ambulatoryjnych, finansowanych przynajmniej na poziomie podstawowym, świadczonych blisko miejsca zamieszkania,

- sprawiedliwe - równe i jednakowe traktowanie w systemie zdrowotnym związane m. in. z dostosowaniem kosztów usług medycznych do zdolności wnoszenia opłat przez pacjentów oraz rozmieszczenie przestrzenne usług adekwatne do struktury potrzeb zdrowotnych populacji zamieszkałej na danym terenie,

- wolny wybór lekarza zarówno w przypadku ubezpieczenia państwowego jak i prywatnego, swoboda wyboru pomiędzy różnymi usługodawcami świadczeń medycznych, podstawowych i specjalistycznych, oraz swoboda wyboru płatnika,

- respektowanie przez system zdrowotny praw obywatelskich i praw pacjenta gwarantowanych standardami konwencji międzynarodowych ratyfikowanych przez Polskę oraz krajowymi i wewnętrznymi (instytucjonalnymi) dokumentami obsługującymi sektor zdrowotny.

Realizacja powyższych zadań przez funkcjonalnie zorganizowany system zdrowotny leży w gestii państwa, niezależnie od tego czy będzie to sektor publiczny czy prywatny obsługujący potrzeby zdrowotne obywateli. Państwo jest zobowiązane do takich legislacji, które zapewnią strategiczne cele zdrowotne zarówno dla jednostek jak i w zakresie zdrowia publicznego. Przyjmowane w trakcie reformowania systemu zdrowotnego rozwiazania organizacyjne i prawne nie spełniały podstawowej powinności normatywnej - konstytucyjnego prawa do ochrony zdrowia obywateli. Polska pierwszą reformę zaczęła w $1999 \mathrm{r}$. od decentralizacji rozumianej jako delegowanie uprawnień z instytucji centralnych do terenowych za planowanie, decyzje, gromadzenie i alokację zasobów ochrony zdrowia. Głównym celem było zastąpienie budżetowego finansowania ochrony zdrowia finansowaniem opartym na powszechnym ubezpieczeniu zdrowotnym ${ }^{1}$. Poza pozytywnymi konsekwencjami reformy, jak np. racjonalizacja kosztów, możliwość wyboru lekarza, polepszenie jakości świadczeń w części regionów, wskazywano również na skutki negatywne: zwiększenie nierówności w dostępie do świadczeń zdrowotnych w poszczególnych regionach, słabe mechanizmy koordynacji działań kas chorych, brak środków na realizację usług zdrowotnych, ograniczenie liczby świadczeń. W ocenie społecznej system opieki zdrowotnej nie realizował podstawowych powinności i celów reformy. Druga reforma rozpoczęła się w 2003 r. i polegała na centralizacji instytucji płatnika i zastąpieniu kas chorych ogólnokrajowym Narodowym Funduszem Zdrowia.

${ }^{1}$ W 1997 r. uchwalona została Ustawa o powszechnym ubezpieczeniu zdrowotnym dająca podstawy późniejszych reform zdrowotnych. Niestety, zanim weszła w życie została kilkakrotnie znowelizowana przez kolejne rządy. 
Podstawowe zastrzeżenia wobec działania opieki zdrowotnej w tych ramach sprowadzają się do zarzutów: nieefektywna polityka finansowa centrali NFZ, narzucane kontrakty i sztywne wyceny usług, kontrakty nie uwzględniają lokalnych uwarunkowań, dyskryminacja niepublicznych świadczeniodawców, niewłaściwa alokacja zasobów. Generalny zarzut jaki się stawia kolejnym etapom reformy systemu zdrowotnego to jego upolitycznienie i niezbyt dobre pod względem legislacyjnym opracowanie reform. Politycy traktowali system opieki zdrowotnej jako obszar załatwiania partykularnych interesów partii politycznych, określonych grup społecznych i zawodowych. Przypomnijmy, że 7.01.2004 r. Trybunał Konstytucyjny uznał Ustawe o powszechnym ubezpieczeniu zdrowotnym za akt prawny niezgodny z zasadami Konstytucji RP. Zwrócono uwagę na złamanie zasad demokratycznego państwa prawnego oraz ochrony zdrowia. Istnieje konflikt pomiędzy konstytucyjną zasadą równości do ochrony zdrowia, a limitowaniem świadczeń zdrowotnych $\mathrm{w}$ ramach powszechnego ubezpieczenia zdrowotnego. Nie do pogodzenia jest również sprostanie zasadzie leczenia według aktualnej wiedzy medycznej wobec ograniczonych środków finansowych. Kolejne nowelizacje ustaw i zmiany rozporządzeń ministerialnych miały usprawnić system, a w szczególności sprecyzować zasady odpowiedzialności za ochronę zdrowia obywateli, pomiędzy NFZ a władzami rządowymi (Ministerstwo Zdrowia) oraz władzami samorządowymi. Prezentacje medialne konfliktów w opiece zdrowotnej pokazywały bezradność organizacyjną i opieszałość urzędniczą w tragicznych sytuacjach niedoboru leków onkologicznych bądź niewykonania usługi medycznej ponieważ zakontraktowany limit operacji został wyczerpany po kilku miesiącach. Przypomnijmy, że zasadniczych ustaw i rozporządzeń regulujących funkcjonowanie systemu zdrowotnego jest ponad 50, łącznie z innymi, mającymi wpływ na działania opieki zdrowotnej jest ponad 100 [Kubiak: 2010]. Synchronizowanie przepisów aby sprawnie zaspokajać potrzeby zdrowotne obywateli jest niezwykle trudne. Czy politycy i urzędnicy dobrze sobie z tymi przepisami radzą? Odpowiedź musi być złożona w zależności od tego jakie wskaźniki ewaluacyjne systemu zdrowotnego bierzemy pod uwagę. Poświadczają to przypadki kwalifikowane jako „bezduszne trzymanie się prawa przez personel medyczny” lub „brak wrażliwości systemu na potrzeby pacjentów". W kolejnych odsłonach reformy systemu zaczęto w większym stopniu synchronizować część normatywną systemu z racjonalną optymalizacją nakładów. Zespół opracowujący analizę i wytyczne do zmian systemowych położył nacisk na proces budowy racjonalnej, przyjaznej i oszczędnej opieki zdrowotnej $^{2}$. Przyjmując punkt widzenia pacjenta, świadczeniodawców i polityki

2 Zespół ds. Systemowych Przekształceń w Ochronie Zdrowia kierowany był przez prof. C. Włodarczyka; znaleźli się w nim specjaliści z różnych dziedzin naukowych i praktycy, m.in. lekarze, ekonomiści, politycy zdrowotni, etyk. Interdyscyplinarny charakter zespołu świadczył o wielowymiarowym podejściu do zmian w systemie zdrowotnym. Ustalenia zespołu stanowiły niestety tylko rodzaj ekspertyzy i wykorzystane zostały jako materiał dla polityków. 
zdrowotnej opracowano zasady nowego sytemu zdrowotnego. Niestety, słuszne były obawy przewodniczącego projektu: Konieczne jest jeszcze przezwyciężenie różnorodnych barier politycznych, zmiana stereotypów, a także przezwyciężenie myślowej $i$ instytucjonalnej inercji [Włodarczyk: 2004]. We wszystkich nowych propozycjach zwraca się uwagę na konieczność uporządkowania następujących problemów: świadczeń gwarantowanych i priorytetowych, katalogu zasobów i skupienie ich na działaniach zwiększających bezpieczeństwo zdrowotne populacji, działaniach oszczędnościowych związanych ze skuteczniejszą organizacją udzielania świadczeń, potrzebach pacjentów poprzez zniesienie barier dostępności i troskę o ich zdrowie. Warto w tym kontekście odwołać się do badań WHO, według których wskaźnikami funkcjonowania systemów zdrowotnych jest stopień realizacji celów nadrzędnych, do których zalicza się: a) zdrowie społeczeństwa, b) wrażliwość systemu na potrzeby pacjentów w zakresie nie związanym bezpośrednio $\mathrm{z}$ aspektem medycznym, c) sprawiedliwość $\mathrm{w}$ zakresie finansowania opieki zdrowotnej. Szczególnie należy podkreślić znaczenie jakie przykładają urzędnicy i decydenci WHO do responsywności systemu zdrowotnego. W dokumentach pisze się o dwóch wskaźnikach responsywności: podmiotowym traktowaniu pacjenta - mając na myśli poszanowanie jego godności, dyskrecję, autonomię oraz o orientacji na klienta - przez co rozumie się szybkość reagowania, jakość infrastruktury, dostęp do wsparcia, wybór świadczeniodawców. W badaniach w których klasyfikowano 191 państw Polska znalazła się na różnych miejscach pod względem spełniania kryteriów: poziom osiagnięcia celów systemu zdrowotnego - 34, stan zdrowia populacji - 45, wrażliwość systemu 50, sprawiedliwość obciążeń finansowych - 150 [WHO: 2000].

Proces reformy powinien prowadzić do lepszej, w ocenie społecznej, realizacji zadań nakładanych na system zdrowotny we wszystkich obszarach i we wszystkich pionach gdzie realizowane są potrzeby zdrowotne obywateli. Zagadnieniem kluczowym dla losów reformy było i jest rozstrzygnięcie dylematu, w jakim stopniu opieka zdrowotna ma być darem, a w jakim towarem [Payne: 2001]. Gdzie przebiega granica pomiędzy prawami rynku zmuszającymi do traktowania usług medycznych jako towaru, a społecznymi oczekiwaniami w których opieka zdrowotna traktowana jest jako dar? Większość naszego społeczeństwa nadal interpretuje usługi medyczne w kategoriach ,publicznej darmowej opieki". Mentalnie społeczeństwo polskie nie zaabsorbowało informacji, że tzw. „państwowa” lub „publiczna” z nazwy opieka zdrowotna jest finansowana głównie z Powszechnego Ubezpieczenia Zdrowotnego, a rachunek ekonomiczny dotyczy jej również. Pacjenci i personel medyczny, pomimo wielu lat reformy, nadal kierują swoje pretensje i skargi do państwa, a w szczególności Ministerstwa Zdrowia, obarczając je winą za dysfunkcje systemu zdrowotnego. Adresatem petycji strajkowych jest Rząd lub Ministerstwo Zdrowia, które w osobach rzeczników prasowych wyjaśniają, że rozstrzyganie sporów i konfliktów winno być prowadzone na szczeblu dyrektorów szpitali bądź władz samorządowych. 
Hasło „mniej państwa więcej rynku” pojawiało się w wypowiedziach niektórych polityków i przedstawicieli zawodów medycznych. Idea wolnego rynku usług zdrowotnych została poddana krytyce [Arrow: 1979], zanegowano możliwość funkcjonowania w pełni wolnego rynku usług medycznych $\mathrm{m}$. in. powołując się na argumenty moralne dotyczące solidaryzmu społecznego w sytuacjach trudnych. Specyfiką rynku usług zdrowotnych jest ryzyko i niepewność towarzysząca pojawieniu się potrzeb zdrowotnych, niepewność dotycząca wyników leczenia, brak możliwości zweryfikowania kupowanej usługi przed jej realizacja, asymetria pomiędzy świadczeniodawcą a usługobiorcą.

Reforma systemu zdrowotnego ujawniła sytuacje, które działają destrukcyjnie na funkcjonowanie systemu i tworzą podstawy do negatywnej oceny całości systemu. Tworzą równocześnie ryzyko (utraty zdrowia, choroby, uszkodzenia ciała, utraty sprawności fizycznej lub psychicznej, czasowej niezdolności do pracy) związane z różnymi poziomami funkcjonowania opieki zdrowotnej. Ryzyko może być postrzegane w tym obszarze opieki zdrowotnej jako: a) skutek modernizacji biomedycyny i konsekwencja rozwoju nowoczesnych biotechnologii, b) skutek złej organizacji i dysfunkcji systemu usług zdrowotnych, c) związane z dyskursem bioetycznym i bioprawnym, d) kliniczne, wynikające $\mathrm{z}$ procedur stosowanych $\mathrm{w}$ diagnozie, leczeniu i rehabilitacji pacjentów, e) epidemiologiczne obejmujące powszechne i zakaźne schorzenia populacji ludzkiej f) farmakologiczne, związane z wynalazkami, produkcją, dystrybucją i użytkowaniem leków, g) ubezpieczeniowe jako instrumentów polityki zdrowotnej i zabezpieczenia społecznego [Gałuszka, Legiędź-Gałuszka: 2008]. W wyliczeniu tym nie bierzemy pod uwagę tzw. indywidualnych czynników ryzyka związanych z różnymi kwestiami jak np. ryzyko genetyczne, styl życia, ,złe prowadzenie", sposoby żywienia. Poniżej wymienione są obszary ryzyka wynikające z organizacji systemu zdrowotnego:

- wycofanie i decentralizacja odpowiedzialności: wycofanie się państwa $\mathrm{z}$ różnych zobowiązań w dziedzinie finansowania i organizowania usług zdrowotnych; przerzucanie odpowiedzialności przez administrację rządową za usługi zdrowotne i dostęp do świadczeń na podmioty słabsze - pacjentów, personel medyczny, ubezpieczyciela;

- komercjalizacja i prywatyzacja szpitali oraz innych zakładów: przekształcenie samodzielnego zakładu opieki zdrowotnej w spółkę prawa handlowego może prowadzić do wyprzedaży zasobów medycznych i nastawienia prywatnych właścicieli przede wszystkim na osiaganie zysku. Nierentowne oddziały szpitalne będą likwidowane, spółki ograniczą zatrudnienie personelu;

- pogłębienie się nierówności społecznych i geograficznych w dostępie do usług medycznych. Pacjent publiczny, finansowany ze środków zakontraktowanych w NFZ będzie gorzej traktowany, wydłużą się kolejki do lekarzy specjalistów, dobro pacjentów zostanie zepchnięte na plan dalszy; 
- pojawi się zjawisko nazwane medlining polegające na unikaniu chorych, którzy generują duże koszty dla szpitala, a za które NFZ nie chce poza zakontraktowanymi procedurami płacić. Preferowane będą racjonalne ekonomicznie lecz watpliwe moralnie zasady menedżerskie: należy unikać chorych, a leczyć zdrowych; należy leczyć bogatych (płacqcych) a unikać biednych (nieptacacych);

- polityzacja i ekonomizacja usług zdrowotnych: spory związane z kontraktowaniem usług zdrowotnych, rosnące koszty administracyjne, przejęcie kontroli nad świadczeniem usług medycznych przez ekonomistów, menedżerów i prawników, nastawienie na zysk zakładów opieki zdrowotnej;

- zintensyfikuje się zjawisko „moralnego hazardu” pacjentów, ubezpieczycieli, zakładów udzielających świadczenia zdrowotne występujące w postaci nadmiernej konsumpcji oraz nadprodukcji świadczeń medycznych. Wzrost zapotrzebowania na świadczenia medyczne i wzrost wydatków spowodowanych zjawiskiem moralnego hazardu wymusza na towarzystwach ubezpieczeniowych neutralizację ponoszonego ryzyka poprzez podwyższenie składek oraz kreowanie zbędnych świadczeń medycznych [Suchecka: 2009];

- patologie organizacyjne i „mroczne praktyki”: stosowane w systemie medycznym dotyczą takich zjawisk jak np. korupcja w relacjach lekarz-pacjent, nepotyzm, ukrywanie błędu jatrogennego, odmowa udzielania świadczenia medycznego w sytuacji zagrożenia życia, formalne przestrzeganie przepisów ze szkodą dla pacjentów, wypalenie zawodowe; działają one destrukcyjnie na funkcjonowanie systemu i tworzą podstawy do negatywnej oceny całości systemu [Gałuszka: 2007];

- szara strefa w gospodarce i zarządzaniu przedsiębiorstwami medycznymi i farmaceutycznymi: korupcja w relacjach lekarz-firma farmaceutyczna, korupcja w zarządzaniu zakładami opieki zdrowotnej i innymi instytucjami medycznymi, procedury przetargów na usługi szpitalne, wprowadzenie leku na listę leków refundowanych, lobbing polityków;

- instrumentalizacja i reifikacja pacjenta oraz dysfunkcjonalność relacji lekarz-pacjent: zakłócenia w komunikowaniu się, ideologia szpitalna, fragmentaryzacja odpowiedzialności lekarskiej, medykomowa, osamotniony pacjent borykający się ze swoimi problemami i obojętna zbiurokratyzowana machina systemu zdrowotnego.

Dziedzina zdrowia publicznego również narażona jest na dysfunkcje organizacyjne wynikające $\mathrm{z}$ kontekstu polityki zdrowotnej Unii Europejskiej. Wprawdzie UE pozostawia opiekę zdrowotną w dyspozycji państw członkowskich i nie ma w tym obszarze kompetencji formalnych, jednak w temacie zdrowia publicznego ma wiele do powiedzenia. Posługuje się w tym względzie zasadą pomocniczości (zasadą subsydiarności), wedle której nie mieszając się do kształtu polityki zdrowotnej państw członkowskich oraz sposobów organizowania i udzielania świadczeń zdrowotnych państw członkowskich, wywiera wpływ 
pośredni poprzez kształtowanie polityki zdrowia publicznego. Dziedzina zdrowia publicznego narażona jest również na respektowanie różnego rodzaju zaleceń, rozporządzeń i konwencji, które powstały i powstają w ramach instytucji UE. Szczególnie trudne do określenia są relacje powstające na styku dobro indywidualne - dobro wspólne. Interweniują tutaj np. preferencje moralne, polityka zdrowia publicznego, konwencje bioetyczne, pielęgniarstwo wielokulturowe. W latach 2003-2006 realizowano projekt European Public Health Ethics Network (EuroPHEN) ${ }^{3}$, którego celem było badanie etycznych problemów i dylematów związanych z polityką zdrowia publicznego. Konstatacja dotycząca sprzeczności pomiędzy interesami publicznymi i prywatnymi w ochronie zdrowia była punktem wyjścia do analizy, w jaki sposób polityki zdrowotne różnych państw radzą sobie z tym problemem i godzą często rozbieżne interesy. Rozważano takie problemy jak: organizacja i struktury zdrowia publicznego, polityka szczepień ochronnych, uczestnictwo w badaniach klinicznych, ochrona przed chorobami zakaźnymi, wpływ środowiska na zdrowie, przepisy bezpieczeństwa i higieny pracy. Przykładem, który ostatnio był przedmiotem zainteresowania opinii publicznej, jest dyrektywa unijna dotycząca zakupu szczepionki przeciwko grupie AH1N1. Jak wiadomo polskie Ministerstwo Zdrowia nie zastosowało się do dyrektywy unijnej dzięki czemu zaoszczędziliśmy znaczne środki finansowe; straty państw, które zakupiły szczepionką były znaczące.

\section{Racjonowanie usług zdrowotnych}

Racjonowanie świadczeń zdrowotnych jest koniecznością wynikająca z przyczyn ekonomicznych i medycznych. Ponieważ żadnego państwa nie stać na zaspokojenie wszystkich potrzeb zdrowotnych obywateli, pojawia się problem etycznego uzasadnienia racjonowania ograniczonych zasobów medycznych. Dostęp do pełnego zakresu wysokiej jakości usług medycznych jest mitem, którego ramy określają aspiracje propagandowe polityków oraz roszczeniowe postawy obywateli. Szczególny problem pojawia się gdy zabraknie środków na leczenie niestandardowe; pacjentom poszkodowanym trudno zaakceptować, że to właśnie w leczeniu ich przypadku zabrakło jakichś środków. Maja przecież wiedzę, że Konstytucja Rzeczypospolitej Polskiej w art. 68 zapewnia równy dostęp każdego obywatela do świadczeń finansowanych ze źródeł publicznych. Zasada sprawiedliwości „każdemu według potrzeb” jest silnie zakorzeniona w myśleniu o społecznym wyrównywaniu szans rekompensującym braki tzw. loterii życiowej. Według analiz K. Szewczyka [2009b] można wyróż-

${ }^{3}$ Projekt finansowany był z Piątego Ramowego Programu Komisji Europejskiej(QLG6-CT2002-02320), uczestniczyło w nim dwudziestu jeden partnerów z szesnastu krajów. Ze strony polskiej partnerem projektu był Instytut Zdrowia Publicznego Collegium Medicum Uniwersytetu Jagiellońskiego w Krakowie. 
nić cztery podstawowe formy racjonowania: jawne, niejawne, ekonomiczne, nieekonomiczne oraz cztery reguły racjonowania: etyczne, wyboru między jednostkami, skutku i proceduralne. Wiele przykładów praktycznych racjonowania, które autor omawia, pokazuje, że sam problem racjonowania, w którego opisie stosuje się również pojęcia „rozdzielnictwo”, „reglamentacja”, „alokacja”, „dystrybucja" jest metodologicznie skomplikowany, a kryteria stosowane w praktyce decyzyjnej nie odpowiadają potrzebom społecznym. Opieka zdrowotna jest dobrem, które może być racjonowane, posiada bowiem wartość, jej dostępność jest ograniczona, można ją też kontrolować [Szewczyk: 2009b: 14]. Trudność podstawowa polega na tym jak agregację indywidualnych preferencji pacjentów dotyczącą usług zdrowotnych zamienić w preferencję społeczną. Przykładem mogą być trudności z ustaleniem koszyka gwarantowanych świadczeń, który $\mathrm{z}$ definicji nie powinien zawierać wszystkich świadczeń. Społeczne preferencje wyboru z rozważanego zestawu alternatyw medycznych usług pokazują, że zgodę uzyskujemy tylko w przypadku niektórych procedur [Gałuszka: 2003: 105]. $\mathrm{W}$ podstawowym wymiarze dostępnym wszystkim ludziom $\mathrm{w}$ ramach publicznej opieki zdrowotnej, według wszystkich respondentów powinny być finansowane tylko „leczenie w przypadkach ostrych” i ,udzielenie pierwszej pomocy”. $\mathrm{Na}$ końcu listy refundowanych przez publiczną opiekę zdrowotną procedur znalazły się z 10\% akceptacją ,zaburzenia potencji” i „operacje plastyczne”. Zgodę na finansowanie ze środków publicznych mają w 50\% "środki antykoncepcyjne" i ,przerywanie ciąży zgodnie z obowiązującym prawem”. Warto zwrócić uwagę na to, że istniała rozbieżność w preferencjach różnych grup badanych, a także pomiędzy preferencjami respondentów a stanem faktycznym. Przykładowo, „szczepienie przeciwko wirusowemu zapaleniu wątroby typu B” w opinii ponad $80 \%$ respondentów powinno być refundowane, a w czasie kiedy realizowane były badania, było finansowane ze środków publicznych tylko w przypadku niektórych grup zawodowych. Z punktu widzenia analiz socjologicznych ważna jest grupa zasad proceduralnych, według których określa się społeczne priorytety wyboru i szuka publicznego konsensusu. Kluczowe dla analizy tych zasad sa warunki owego wyboru. Według N. Danielsa i J. Sabina [2002] warunkami tymi są: jawność, znaczenie, rewizja, realizacja. W społeczeństwach demokratycznych zasadne staje się pytanie czy proponowane przez politykę zdrowotną i ekonomikę zdrowia rozwiązania są przedmiotem publicznej debaty i czy w ich sprawie osiagnięto społeczny konsensus. Jawność warunków rozdzielnictwa powinna wpłynąć na poprawę wizerunku opieki zdrowotnej, a zarazem ma tworzyć akceptowane społecznie prawo precedensowe dostępu do środków medycznych osób szczególnie poszkodowanych przez „loterię życia”. Znaczenie rozumiane jest jako konieczność oparcia rozdzielnictwa usług zdrowotnych na kryteriach efektywności kosztowej procedur poddanych społecznej ocenie w badaniach empirycznych. Rewizja dotyczy procedury mechanizmów weryfikacji i zmiany priorytetów w koszykach świadczeń zdrowotnych, które na wsku- 
tek postępu w nowoczesnych technologiach medycznych oraz zmiany społecznej, zyskują bądź tracą akceptację społeczną. Zasada realizacji stoi na straży poprawności stosowania kryteriów reglamentacji. Powołane są do tego instytucje, które mają określać i badać zasadność praktycznego wdrożenia danego leku, procedury klinicznej czy wynalazku. W Polsce zadania takie pełni Agencja Oceny Technologii Medycznych, odpowiednik Health Technology Assessment (HTA), których działalność ma zapewnić dopuszczenie na rynek zdrowotny zweryfikowanych procedur i technologii ${ }^{4}$. Ważność tych instytucji dla racjonalności i funkcjonalności systemu zdrowotnego potwierdzona jest zakresem działania i odpowiedzialności za zdrowie indywidualne i publiczne. W ekspozycjach medialnych AOTM obwiniana jest czasami za niedopuszczenie na rynek leku z tzw. terapii niestandardowych, co odbierane jest jako uniemożliwienie zastosowania nowoczesnych technologii. Pacjenci indywidualni gotowi są ponieść ryzyko uczestniczenia $w$ eksperymencie medycznym, gdyż szukają dla siebie leku przedłużającego ich życie. Społeczna preferencja lub kalkulacja użyteczności danej technologii medycznej może nie odzwierciedlać indywidualnego ryzyka i preferencji.

H. Peyton Yong [2003: 39] zwraca uwagę na to, że pewne dobra medyczne są niepodzielne, tzn. każdy może otrzymać co najwyżej jednq jego jednostkę, przy czym zasób nie wystarcza dla wszystkich, w związku z tym konieczne jest przyjęcie jakichś zasad racjonowania. W rozwiązaniu tych problemów proponuje się stosować następujące rozwiązania: wymuszoną równość, loterie, kompensacje, kolejki, listy priorytetowe. Polski system zdrowotny podejmował różne próby rozwiązywania dylematów związanych z ograniczonymi środkami medycznymi. Jedną z nieudanych swego czasu zasad reglamentacyjnych było ustanowienia za czasów pełnienia funkcji ministra zdrowia przez prof. Balickiego, podwójnych kolejek do ograniczonych usług, np. operacji. Pierwsza kolejka obejmowała wszystkich potrzebujących, która powstawała w momencie skierowania pacjenta na operację. Ponieważ czas oczekiwania w przypadku niektórych zabiegów wynosił 2 lata, a pacjenci byli w pilnej potrzebie zdrowotnej wymyślono druga, z założenia krótszą kolejkę tzw. komercyjną. Za usługę wykonaną w ramach tej kolejki pacjent musiał zapłacić. Procedury tej zaprzestano, ponieważ jak się okazało nie było wtedy podstaw prawnych do ich legalizacji. Obecnie rozwiazanie tego typu ma uzasadnienie formalnoprawne, bowiem szpitale, które przekształciły się w spółki prawa handlowego, mogą wykonywać priorytetowe usługi komercyjne. Już choćby powyższe przykłady pokazują, że racjonowanie usług zdrowotnych dotyka szeregu problemów natury etycznej i ekonomicznej, które są trudne do rozstrzygnięcia. Teorie wyboru społecznego przedstawiają jakimi zasadami powinniśmy się kierować, dokonując wyboru z przed-

\footnotetext{
${ }^{4}$ Instytucji tego typu jest wiele, różnią się statusem, przedmiotem zainteresowania i badań oraz zakresem terytorialnym, np. European Medicines Agency (EMA) - Europejska Agencja ds. Leków; Stowarzyszenie na Rzecz Dobrej Praktyki Badan Klinicznych w Polsce, www.gcppl.org.pl.
} 
stawionych alternatyw, jednakże nie ma jednej racjonalnej zasady, na którą godzą się wszyscy. W przypadku wyborów dotyczących zdrowia i życia człowieka interweniują różne czynniki. Koncentracja opieki zdrowotnej na indywidualnym pacjencie potwierdza moralny indywidualizm medycyny kręgu kultury europejskiej [Łuków: 2004]. Przekonanie o tym, że ostatecznym punktem powinności dla opieki zdrowotnej nie jest zdrowie publiczne jako abstrakcyjna całość, lecz konkretny człowiek w swojej złożonej egzystencjalnie sytuacji potrzeby zdrowotnej, ustawia intensywność sporów dotyczących wartości życia i powinności opieki zdrowotnej. Wydaje się, że integralną częścią owych sporów powinna być etyka zdrowia publicznego, bowiem dopiero wtedy potrzeby zdrowotne jednostki znajdą pełniejszy kontekst i uzasadnienie moralne dla racjonowania środków medycznych.

\section{Zakończenie}

Przedstawione dylematy i konflikty moralne systemu zdrowotnego nie maja aspiracji wyczerpania tematu. Prezentacja dylematów moralnych wymaga obszerniejszych i procesualnych badań ponieważ system zdrowotny ewoluuje, a zmiany w przepisach prawnych, odkrycia naukowe i postęp biotechnologiczny tworzą nowe dylematy. Ryzyko jakie niosą zmiany w technologiach medycznych musi być przedmiotem także namysłu bioetycznego. Modernizacja medycyny przebiega na wielu poziomach i dotyczy różnych obszarów, a skutki jej bezpośrednio odczuwają pacjenci. Postulowana przez U. Becka [2009] „,modernizacja refleksywna" w obszarze medycyny powinna dotyczyć badań i konfrontacji ze skutkami społeczeństwa ryzyka biomedycznego. Bioetyka regulatywna i bioprawo jest odpowiedzią na zapotrzebowanie medycyny do ustalenia obligatoryjnych zasad postępowania, zaś rozwijana nowa subdyscyplina - bioetyka kulturowa jest ukłonem w stronę koncepcji medycyny wielokulturowej, uwzględniającej obok standardów klinicznych lokalne aksjologie i ideologie szpitalne. Docenienie roli ekspertów w społeczeństwie ryzyka biomedycznego prowadzi do swoistego paradoksu. Z jednej strony mamy świadomość, że współczesne konflikty bioetyczne cechuje niekonkluzywność i nierozstrzygalność na warunkach proponowanych przez ekspertyzy naukowe zorientowane na określony system wartości, z drugiej zaś powołujemy komisje bioetyczne po to, aby w dyskursie publicznym wypracować konsensus. Profesjonaliści z branży medycznej mają duży wpływ na nasze życie; jak słusznie podkreślał M. Foucault [1998] medycyna jest władzą - wiedzy i niechętnie udostępnia teren swojego działania dla laików. Walka profesjonalistów z tzw. medycyną niekonwencjonalną pokazuje, że spory są nie tylko merytoryczne lecz dotyczą zawłaszczania przedmiotu działań i odbierania klientów. Lecznictwo niemedyczne stosujące metody niekonwencjonalne stworzyło sieć różnych komercyjnych instytucji 
zajmujących się zdrowiem ludzi [Piątkowski: 2008]. Lekarze muszą sobie uświadomić, że pacjent zawiedziony niedoskonałością systemu zdrowotnego będzie szukał pomocy poza nim. Tendencje irracjonalne ludzi dotyczą także ich zdrowia, duża populacja ludzi szuka pomocy zdrowotnej u różnego rodzaju „szamanów i ekspertów wschodniej medycyny”. Ryzyko wynikające z popularności medycyny niekonwencjonalnej powinno być monitowane w celu określenia skuteczności tego typu leczenia. Warto więc zastanowić się w jaki sposób, jako pacjenci, możemy chronić swoją autonomię moralną i podmiotowość również w obsłudze naszego zdrowia przez lecznictwo niekonwencjonalne. Personel medyczny i pacjenci muszą intensywnie pracować nad tym, by moralny i humanistyczny aspekt medycyny nie został zunifikowany przez racjonowanie usług zdrowotnych i procedury biotechnologiczne. Konieczna jest praca nad poprawą stanu zdrowia społeczeństwa i wzrostem świadomości zdrowotnej; nacisk położony powinien być na rozwój socjalizacji zdrowotnej, promocję zdrowia i profilaktykę zdrowotną.

\section{Bibliografia:}

Arrow Kenneth J., 1979, Lecznictwo z punktu widzenie niepewności i ekonomii dobrobytu, [w:] Eseje z teorii ryzyka, PWN, Warszawa.

Aszyk Piotr SJ, 1998, Konflikty moralne a etyka, Wydawnictwo WAM, Kraków. Beauchamp Tom L., Childress James F., 1996, Zasady etyki medycznej, Książka i Wiedza, Warszawa.

Beck Ulrich, 2009, Ponowne odkrycie polityki: przyczynek do teorii modernizacji refleksywnej, [w:] U. Beck, A. Giddens, S. Lash (red.), Modernizacja refleksywna. Polityka, tradycja i estetyka w porzadku spotecznym nowoczesności, Wydawnictwo Naukowe PWN, Warszawa.

Daniels Norman, Sabin James E., 2002, Setting Limits Fairly. Can We Learn to Share Medical Resources?, Oxford University Press, Oxford.

Foucault Michael, 1998, Trzeba bronić społeczeństwa. Wyktady w College de France, Wydawnictwo KR, Warszawa.

Gabe Jonathan, 1995, Health, medicine and risk: the need for a sociological approach, [w:] J. Gabe (ed.) Medicine, Health and Risk, Blackwell Publishers/Editorial Board, Cambridge.

Gałuszka Mieczysław, 2003, Społeczne i kulturowe powinności medycyny. Tożsamość zawodowa i atrofia moralna, Wrocławskie Towarzystwo Naukowe Wydawnictwo, Wrocław.

Gałuszka Mieczysław, 2007, Korupcja i działania antykorupcyjne w systemie ochrony zdrowia, „Lekarz Rodzinny”, nr 9.

Gałuszka Mieczysław, Legiędź-Gałuszka Małgorzata, 2009, Medycyna i zdrowie w społeczeństwie ryzyka, [w:] M. Gałuszka (red.), Zdrowie i choroba w spo- 
teczeństwie ryzyka biomedycznego, Biuro Promocji i Wydawnictw Uniwersytetu Medycznego w Łodzi, Łódź.

Gordon Thomas, Edwards Sterling W., 2009, Rozmawiać z pacjentem, Wydawnictwo Academica, Warszawa.

Hansen Mark.J., Callahan Daniel (red.), 1999, The Goals of Medicine. The Forgotten Issues in Health Care Reform, Georgetown University Press, Washington.

Jonsen Albert R., 1992, Modern Medicine as a Risk to Society, [w:] M. Waterstone (ed.), Risk and Society: the Interaction of Science, Technology and Public Policy, Kluwer Academic Publishers, Dordrecht, Boston, London.

Kubiak Rafał, 2010, Prawo medyczne, Wydawnictwo C.H. Beck, Warszawa.

Krajewski Siuda Krzysztof, Romaniuk Piotr, 2005, Analiza polskich reform zdrowotnych (decentralizacja i centralizacja) w oparciu o model przestrzeni decyzyjnej, „Zdrowie Publiczne i Zarządzanie”, t. III, nr 1.

Łuków Paweł, 2004, Racjonowanie świadczeń a troska o dobro pacjenta, „Zdrowie Publiczne i Zarządzanie”, t. II, nr 1.

Mariański Janusz, 2001, Kryzys moralny czy transformacja wartości?, Towarzystwo Naukowe Katolickiego Uniwersytetu Lubelskiego, Lublin.

Szewczyk Kazimierz, 2009a, Bioetyka. Medycyna na granicach życia, t. 1, Wydawnictwo Naukowe PWN, Warszawa 2009.

Szewczyk Kazimierz, 2009b, Bioetyka. Pacjent w systemie opieki zdrowotnej, t. 2, Wydawnictwo Naukowe PWN, Warszawa.

Suchecka Jadwiga, 2010, Ekonomia zdrowia i opieki zdrowotnej, Oficyna Kluwer, Warszawa.

Studzińska-Pasieka Kinga, 2009, Paradygmat profesji $w$ doświadczeniach zawodowych lekarzy i opiniach studentów medycyny. Analiza na przykładzie tódzkiego środowiska medycznego, Praca doktorska - maszynopis, Uniwersytet Medyczny w Łodzi.

Ślęczek-Czakon Danuta, 2004, Problem wartości i jakości życia w sporach bioetycznych, Wydawnictwo Uniwersytetu Śląskiego, Katowice.

Ślipko Tadeusz SJ, 2002, Zarys etyki ogólnej, Wydawnictwo WAM, Kraków.

Payne Jan, 2001, Czy ustugi medyczne maja być darem, czy towarem?, [w:] A. Alichniewicz, A. Szczęsna (red.), Dylematy bioetyki, Akademia Medyczna w Łodzi, Łódź.

Piątkowski Włodzimierz, 2008, Lecznictwo niemedyczne w Polsce tradycja i wspótczesność, Wydawnictwo Uniwersytetu Marii Curie-Skłodowskiej, Lublin.

Purtilo Ruth, 2005, Ethical Dimensions in the Health Professions, Elsevier Saunders, Philadelphia, Pensylvania.

WHO, Highlights on health Germany. WHO Regional Office for Europe, European Commission, 1999. 
WHO, The World Health Report 2000. Health Systems: Improving Performance, World Health Organization, 2000.

Włodarczyk Cezary, Paździoch Stefan, 2001, Systemy zdrowotne. Zarys problematyki, Wydawnictwo Uniwersytetu Jagiellońskiego, Kraków.

Włodarczyk Cezary, 2003, Reformy zdrowotne. Uniwersalny kłopot, Wydawnictwo Uniwersytetu Jagiellońskiego, Kraków.

Young H. Peyton, 2003, Sprawiedliwy podziat, Wydawnictwo Naukowe Scholar, Warszawa.

\title{
MORAL DILEMMAS AND CONFLICTS OF DUTY IN POLISH HEALTH CARE SYSTEM VERSUS PROBLEM OF HEALTH RISK
}

\begin{abstract}
Summary
Paper presents problems related to health care reform in Poland in the context of health policy and satisfying health needs of the society. Public health care is permanently bothering with distribution and allocation of insufficient resources. The need for rationing access to health care services causes several moral dilemmas and implies conflicts of duty. Limited medical resources are allocated according to vague and generally socially unaccepted criteria. The paper discusses: goals of health care system, moral problems associated with health care reform, rules of rationing of health care benefits and risk resulting from dysfunctional construction of health care system. Patients express their dissatisfaction and believe that health care system is not responsive enough. There is a need for public debate and social acceptance of health risk, which is related to health policy and functioning of health care system.
\end{abstract}

Key words: health care reform, rationing of medical services, responsibility for health, medical ethics, health and risk. 